\title{
How Does Corporate Governance Influence Hedging Strategy? An Empirical Study
}

\author{
Lilia Rekik ${ }^{1} \&$ Asmâa Alaoui Taib ${ }^{2}$ \\ ${ }^{1}$ School of Administrative Sciences, University of Quebec, Canada \\ ${ }^{2}$ National School of Business and Management, Sidi Mohamed Ben Abdallah University, Fez, Morocco \\ Correspondence: Lilia Rekik, School of Administrative Sciences, University of Quebec, Quebec, QC., G1K 9H6, \\ Canada. Tel: 1-418-657-2747. E-mail: lilia.rekik@teluq.ca
}

Received: September 25, 2018

Accepted: November 13, 2018

Online Published: November 20, 2018

doi:10.5539/ijef.v10n12p115

URL: https://doi.org/10.5539/ijef.v10n12p115

\begin{abstract}
This paper investigates the influence of corporate governance on the choice of hedging instruments. Using a panel data of 370 firm-year observations from gold mining industry, we found that boards with a strong presence of institutional investors as directors were more likely to defend shareholders' interests in decisions on how to hedge firm exposure. Results also indicated that firms whose managers had risk incentives induced by stock options were more likely to use insurance strategies (put options), while CEO equity ownership was positively correlated with linear hedging (forwards, spot-deferred contracts, and gold loans).
\end{abstract}

Keywords: risk management, corporate governance, CEO compensation, ownership structure, derivative instruments, hedging strategy

\section{Introduction}

Early studies in risk management attempted to determine why firms should hedge, but few have investigated how firm should hedge. Our understanding of how companies choose derivative financial instruments to manage their risk is limited. The choice of hedging instruments is clearly an important issue for any firm that hedges. To shed light on this subject, this study will analyze the choice of derivative hedging instruments by non-financial firms in the North American gold mining industry (linear versus options or non-linear strategies).

Some risk management studies have paid particular attention to the use of options and have predicted when firms should use non-linear strategies to hedge their risk. Adler and Detemple (1988) showed that borrowing and short-selling constraints can create non-linear exposures and hence justify the use of options. Froot, Scharftein, and Stein (1993) also demonstrated that in the case of a financially constrained firm whose future capital expenditures are a non-linear function of a certain risk exposure, the optimal hedging strategy to maximize firm value is based on options. In the extent of Froot et al. (1993)'s model, Adam (2009) found that firms with relatively high investment expenditures were more likely and more extensive users of insurance (put options) instead of linear strategies. If capital expenditures were large enough and were a non-linear function of the future gold price, an options strategy with puts provided better coverage than a linear strategy. Furthermore, Adam (2009) found three types of options strategies based on the firms' characteristics. First, the largest and least financially constrained firms that are the most likely to hedge their price risk by buying puts (put strategies). Secondly, the more financially constrained firms that finance the purchase of puts by selling calls (collar strategies), and thirdly, the most financially constrained firms that use strategies involving selling calls without purchasing puts (call strategies). Thus, the common results of these studies are consistent with the hypothesis that if the exposure is non-linear, the optimal hedging strategy will also be non-linear, as well as with the hypothesis that the least financially constrained firms buy options while the most financially constrained firms sell options.

The majority of previous studies were theoretical models that attempted to rationalize hedging strategy using firms' financial attributes. Corporate governance characteristics as a means to explain the choice of hedging strategies remains mostly uninvestigated. Tufano (1996) provided the primary evidence that managerial motives are a determinant of hedging policy. Managers holding higher percentages of a firm's equity were more likely to use derivative securities to manage the risk of changes in gold prices, while managers with more stock options 
tended to use fewer derivatives. Rogers (2002) and Rajgopal and Shevlin (2002) also showed a negative relation between risk-taking incentives induced by managerial option-based compensation and corporate derivative holdings. However, Géczy, Minton, and Schrand (1997) and Haushalter (2000) failed to find an association when they examined currency derivative usage in non-financial Fortune 500 firms and oil and gas producers respectively. Carpenter (2000) investigated the impact of stock options on managerial incentives to manage risk. As the volatility of the firm's stock returns increased, payoffs from options became more important. This effect should, ceteris paribus, motivate managers to hedge less.

Other studies have examined the impact of governance strength on firms' decisions regarding how to hedge firm exposure. Lel's cross-country analysis (2012) found that firms with strong governance used derivatives in tandem with their financial policies and to eliminate currency risk, while firms with weak governance used derivatives for managerial and contractual reasons. Whidbeea and Woharb (1999) and Borokhovich, Brunarski, Crutchley, and Simkins (2004) showed that firms with a higher proportion of independent directors on the board were more likely to use interest rate derivatives, while boards with a lower proportion of independent directors left their currency exposure partially hedged, or in Stulz's (1996) words, they selectively hedged.

Using a data set of listed New Zealand companies, Marsden and Prevost (2005) supplemented the United States-based literature and found that companies with a higher proportion of outside directors were less likely to use financial derivatives. They cited the role of the legislative and regulatory environment to explain their findings. Borokhovich et al. (2004) and Dionne and Triki (2005) extended the literature, linking board characteristics to risk management policy by considering variables such as board size, presence of a bank executive, and financial background of directors sitting on the board and audit committees. They found that these characteristics had no significant effect on derivative use.

Bettis, Bizjak, and Kalpathy (2015) examined 2,000 hedging transactions from 1996 to 2006 in order to provide empirical findings on the hedging instruments used by corporate insiders (i.e., CEOs, CFOs, board chairmen, corporate directors, and beneficial owners) and their motivations for hedging. Their results were consistent with the notion that some transactions allowed insiders to trade opportunistically to hedge their equity positions.

Our paper contributes to an emerging body of research that attempts to explain which governance attributes firms should determine their hedging instruments' choices. We conducted a survey of 30 North American gold mining companies over a 17-year horizon between 1996 and 2012. We considered the gold mining industry to be an excellent sector for studying hedging instrument choice because gold mining firms provide detailed information on their derivatives portfolios and the nature of instruments used. In addition, although gold mining firms all face the same risk exposure - the fluctuation of the future price of gold - they use various hedging strategies; differences in hedging strategies are therefore more likely to be the result of differences in firm-specific characteristics than differences in exposures.

The results of this study revealed that boards with a strong presence of institutional investors as directors were more likely to defend shareholders' interests in decisions on how to hedge firm exposure. This study also showed that firms whose managers had risk incentives induced by stock option compensation were more likely to use options than other firms. The greater the managers' equity investment in the firm, the greater their incentive to choose linear hedging strategies.

The remainder of this paper is organized as follows: Section 2 describes the sample and risk management strategies in the gold mining industry, Section 3 presents the main theories on why companies should use linear or non-linear hedging strategies, Section 4 presents the empirical results, and Section 5 provides a conclusion.

\section{Sample}

\subsection{Sample Selection}

The sample used in this study was the North American gold mining industry from 1996 to 2012. The gold mining industry is an excellent sector for studying hedging instrument choice because of its homogeneity and variety of different hedging strategies. Focusing on this industry had several advantages. First of all, detailed information about derivative holdings is publicly available in this sector, which allowed us to observe the financial risk management activities of these firms. In addition, gold prices have experienced substantial volatility; capital markets have therefore developed a wide variety of techniques to manage this volatility. Finally, gold mining firms are generally less diversified and focus on gold and by-product mining activities only. All of these firms face the common, substantial risk exposure of fluctuating gold prices. Differences in derivatives strategies are therefore less likely to be due to differences in exposures and more likely to be due to differences in certain firm characteristics. 
The starting point for the sample consisted of firms whose primary business segment was SIC Code 1040 or 1041, and we focused on firms managing their gold price risk with derivatives for the fiscal years 1996 to 2012. From this initial sample, we distinguished four categories: companies selling linear contracts, companies buying put options, companies buying collars, and companies selling calls. Firms that could not be classified into one of these categories were excluded from the analysis. Due to the lack of observations, we excluded firms selling calls from the analysis. Financial data was obtained from the Compustat and S\&P Capital IQ databases. Operational data such as cash production costs and exploration expenditures were collected by hand from firms' annual reports and Form 10-Ks. Governance data was hand-collected from proxy statements. The description of independent variables is summarized in Table 1. Table 2 provides descriptive statistics of the 370 firm-year observations for which financial and governance data were available from 1996 to 2012.

Table 1. Description of variables and hypothesis

\begin{tabular}{ll}
\hline Variable & Data description \\
\hline Cash costs & Cash costs include all direct and indirect costs of mining, crushing, processing and general \\
& administrative expenses of the mine, including royalties and mining taxes. \\
Leverage & Book value of long-term debt divided by the book values of common equity, and long-term debt. \\
Exploration expenditures ratio & Exploration expenditures divided by the book-values of total assets. \\
Size & Natural logarithm of market value of all outstanding shares. \\
Quick ratio & Cash and cash equivalents and receivables divided by current liabilities. \\
CEO shares & Natural logarithm of number of common shares owned. \\
CEO stock options compensation & Value of options granted divided by total remuneration. \\
Unrelated directors shares & Natural logarithm of market value of common shares held by unrelated directors. \\
Institutional investors & Number of institutional administrators divided by board size. \\
Block holder & Percentage of common shares owned by the large block holders (\% ownership at least 5\%) \\
& excluding officers and directors. \\
\hline
\end{tabular}

Note. This table lists the independent variables used in the analysis and describes their constructions. The principal data sources are Compustat, S\&P Capital IQ, annual reports and 10-K forms.

Table 2. Description of variables and hypothesis

\begin{tabular}{lcccccc}
\hline Variable & Mean & Median & Standard deviation & Minimum & Maximum & Number of observations \\
\hline Cash costs & 349.5824 & 298.6888 & 176.3732 & 22 & 1062 & 370 \\
Leverage & 0.2086 & 0.0984 & 0.2587 & 0 & 0.9961 & 370 \\
Expenditures ratio & 0.0851 & 0.0152 & 0.3098 & 0 & 4.4841 & 370 \\
Size & 24.3232 & 22.0736 & 7.3646 & 10.0126 & 34.9550 & 370 \\
Quick ratio & 5.0985 & 1.4547 & 25.8836 & 0.0513 & 452.0124 & 370 \\
Unrelated directors shares & 14.2030 & 14.4237 & 2.2672 & 7.8332 & 20.5627 & 368 \\
Institutional investor & 0.0557 & 0 & 0.0942 & 0 & 0.5 & 370 \\
Block holder & 0.0952 & 0 & 0.1455 & 0 & 0.7264 & 370 \\
CEO shares & 12.3414 & 12.4628 & 1.7308 & 7.7191 & 17.8874 & 347 \\
CEO stock option compensation & 0.4288 & 0.3002 & 0.7225 & 0 & 8.3396 & 363 \\
Gold price volatility & 14.9602 & 13.98 & 4.9542 & 5.63 & 29.64 & 370 \\
Use of derivatives & 0.4189 & 0 & 0.4940 & 0 & 1 & 370 \\
Linear strategy & 0.3161 & 0 & 0.4665 & 0 & 1 & 155 \\
Insurance strategy & 0.3636 & 0 & 0.4842 & 0 & 1 & 77 \\
Collar strategy & 0.5050 & 1 & 0.5025 & 0 & 1 & 99 \\
\hline
\end{tabular}

Note. This table reports standard sample statistics for 30 gold mining firms in North America from 1996 to 2012. The use of derivatives dummy variable equals one if a firm had outstanding derivatives positions and zero otherwise. The use of linear strategies is a dummy variable equals one if a firm had linear contracts only and zero if the firm had option derivatives' positions outstanding. The use of insurance strategy dummy variable equals one if a firm had put option positions and zero if the firm had linear strategies positions outstanding. The use of collar strategy dummy variable equals one if a firm had put and call option positions and zero if the firm had linear strategies positions outstanding.

\subsection{Risk Management Strategies in the Gold Mining Industry}

In this section, we will describe hedging strategies adopted by mining firms in order to comprehend the major 
differences between them and to formulate our research hypotheses. Our sample study revealed four categories of derivative strategies for managing gold price risk: selling linear contracts (forwards, gold loans, and spot-deferred contracts), buying puts, buying collars, and selling calls (Note 1).

These four risk management strategies differ in terms of eliminating downside risk and upside potential, initial cash flow committed, and flexibility in structuring the hedge. For example, selling a forward contract eliminates both the risk of loss and the upside potential, whereas buying a put option (out of the money) only covers the loss while maintaining the rise. The sale of a call option (out of the money) does not cover the risk of loss but eliminates part of the rise. On the contrary, purchasing a collar partially eliminates the risk of loss and the upside potential while maintaining an exposure between the two exercise prices. In summary, options strategies result in varying exposure to the risk of gold price fluctuations. A company that uses call or put options retains most of the exposure, whereas a company that uses forwards eliminates all exposure. Firms that use collars maintain intermediate exposure.

Each strategy also has different implications regarding the initial cash flow committed. While a forward strategy is self-financing, purchasing puts options requires a cash payment, while the sale of calls generates a cash inflow (Note 2). The purchase of collars can be self-financing depending on the choice of strike prices.

Finally, hedging strategies differ in terms of flexibility. Options provide more flexibility in structuring a hedge because unlike linear instruments, they are available at several strike prices and make it possible to manage downside and upside risk separately.

\section{How Should Firms Hedge?}

In terms of the selection of derivative type, previous research on how firms elect to hedge is comprised of theoretical models that attempt to rationalize the hedging strategy (linear versus non-linear derivative choice). Adam (2009) examined the use of options strategies in the North American gold mining industry from 1989 to 1999 (10-year horizon). Similarly to Froot, Scharfstein, and Stein (1993), he found that gold mining firms with higher capital expenditures were more likely to use options strategies than linear strategies to hedge their future gold sales, given that capital expenditures are often non-linear for gold mining firms. In addition, Adam (2009) found that financially constrained firms tended to sell options while financially unconstrained firms tended to buy options.

All theories presented so far on how firms should hedge have hypothesized that if the exposure to be hedged is non-linear, then non-linear instruments such as options are necessary to obtain the optimal hedge. However, these theories do not consider corporate governance attributes to explain the choice of hedging strategy. Tufano (1996) provided the primary evidence that managerial motives are a determinant of hedging policy: managers holding higher percentages of a firm's equity were more likely to use derivative securities to manage the risk of changes in gold prices, while managers with more stock options tended to use fewer derivatives. Rajgopal and Shelvin (2002) and Rogers (2002) provided similar evidence in different empirical settings. Using simultaneous regressions, Rogers (2002) and Rajgopal and Shevlin (2002) showed a negative relation between risk-taking incentives induced by managerial option-based compensation and corporate derivative holdings. However, Géczy, Minton, and Schrand (1997) and Haushalter (2000) failed to find an association when they examined currency derivative usage in non-financial Fortune 500 firms and oil and gas producers respectively.

Carpenter (2000) has put forth two opposing effects of stock options on managerial incentive to manage risk. First, when the volatility of the firm's stock returns increased, benefits from options became more important. This effect should, ceteris paribus, encourage managers to protect themselves less. Secondly, when the stock price decreased, the benefits from options became less important. This effect should encourage risk-adverse managers to increase their coverage to avoid a fall in share price. As a result, managers who are paid with stock options may have increased coverage when the second effect prevails. When they empirically separated these two effects, Knopf, Nam, and Thornton (2002)'s results were consistent with this hypothesis. (Note 3)

Other studies have examined the impact of governance strength on how to hedge firm exposure. Lel's cross-country analysis (2012) found that firms with strong governance used derivatives in tandem with their financial policies and to eliminate currency risk, while firms with weak governance used derivatives for managerial and contractual reasons. Whidbeea and Woharb (1999) and Borokhovich et al. (2004) showed that firms with a higher proportion of independent directors on the board were more likely to use interest rate derivatives. Boards with fewer independent directors left their currency exposure partially hedged, or in Stulz's (1996) words, they selectively hedged. Using a data set of listed New Zealand companies, Marsden and Prevost (2005) supplemented the United States-based literature and found that companies with a higher proportion of outside directors were less likely to use financial derivatives. They referenced the role of the legislative and 
regulatory environment to explain their findings. Borokhovich et al. (2004) and Dionne and Triki (2005) extended the literature, linking board characteristics to risk management policy by considering variables such as board size, presence of a bank executive, and financial background of directors sitting on the board and audit committees. They found that these characteristics had no significant effect on derivatives use.

Bettis et al. (2015) examined 2,000 hedging transactions spanning 1996 to 2006 to provide empirical findings on the hedging instruments used by corporate insiders and their motivations for hedging. Bettis et al.'s results were consistent with the notion that some of the transactions allowed insiders to trade opportunistically to hedge their equity positions. Data indicated that a diverse group of insiders (i.e., CEOs, CFOs, board chairmen, corporate directors, and beneficial owners) predominately used four types of securities derivatives: zero premium collars, prepaid variable forwards, exchange trusts, and equity swaps. They also found that the average effective ownership hedge was substantial (30\% on average for certain types of hedges). In a more recent study, Bettis et al. (2015) indicated that boards might allow use of these instruments to reduce agency costs associated with overvalued equity and high equity-based compensation. These instruments tended to be used more often in the place of equity sales when litigation risk is greater and market control is high, such as zero-cost collars and variable forwards that seem to be timed before poor performance.

To our knowledge, this paper is the first to explain which governance attributes firms should explain firms' hedging instruments choices. We conducted a survey of 30 gold mining companies that revealed interesting results, which are presented in the next section.

\section{Results}

We examined the relation between risk management strategy and corporate governance by estimating models regressing dummy variables related to derivative instrument choices on corporate governance variables and control variables. Our variables of interest were the following corporate governance mechanisms: (1) presence of institutional investors on the board, (2) presence of large shareholders, (3) outside directors' ownership, and (4) CEO incentive compensation (proportion of shares and stock options). The control variables introduced in the regression model were the financial firms' characteristics documented in the theoretical models presented in Section 3. This study showed that choosing a derivative instrument (linear or non-linear, i.e. options) was correlated with firms' investment expenditures and financial constraints. Firms' investment expenditures were measured by the ratio of capital expenditures over the book value of total assets, and financial constraints were approximated by cash costs, leverage, quick ratio, and firm size. The description of variables for the following formal regression model is presented in Table 1:

$$
\begin{aligned}
& \text { Firm hedging strategy } \left.=\beta_{0}+\beta_{1}(\text { Board independence })+\beta_{2} \text { (Institutional investors }\right) \\
& \left.+\beta_{3} \text { (Blockholders }\right)+\beta_{4}(\text { CEO shares })+\beta_{5}(\text { CEO stock options })+\beta_{6}(\text { Cash costs }) \\
& +\beta_{7}(\text { Leverage })+\beta_{8}(\text { Capital expenditures })+\beta_{9}(\text { Quick ratio })+\beta_{10}(\text { Firm size })+\varepsilon
\end{aligned}
$$

A description of the variables is presented in Table 1.

\subsection{Univariate Analysis}

Table 3 shows descriptive statistics of the sample firms for the different types of hedging strategies (Note 4). Fifty firm-strategy observations are distributed as follows: 38\% linear strategies (forwards, spot-deferred contracts, or gold loans), 26\% insurance strategies (long puts), and 36\% collar strategies. Some companies adopted more than one strategy during the study period, which is why the number of firm-strategy observations is greater than the number of companies in the sample.

Table 3 on univariate comparisons shows significant differences between options hedgers (insurance and collar hedgers) on one side and linear hedgers on the other side. Firms using options contracts had the highest quick ratio and were the largest (based on the market value of outstanding shares). These firms appeared to face the fewest financial contracts of all firms in the sample. In contrast, firms contracting only linear derivatives tended to be the smallest firms and presented a lowest liquidity ratio (quick ratio). They were also the most likely to face a higher amount of cash costs on average than other categories of firms. Linear hedgers therefore appear to be among the most financially constrained firms in the gold mining industry. Collar hedgers maintained the highest level of leverage ratios. Considering all the companies in the sample that used options in their hedging strategy, we found that the level of corporate debt was on average higher for options hedgers than for linear hedgers. Not all differences presented in the last three columns of Table 3 were statistically significant, but all of these differences were consistent with financial constraint-based theories. These theories predict that less financially constrained firms have a greater probability of buying options, while more financially constrained firms choose self-financing contracts (linear and collar derivatives) or selling options (Note 5). 
Results in Table 3 related to the capital expenditures variable showed no significant difference across the three groups of strategies. However, companies that used options strategies, particularly puts, appeared to be more engaged in investment expenditures. The same results were found during Adam's analysis (2009).

In terms of corporate governance attributes, the presence of institutional investors on the board appeared to encourage the use of long puts, while the presence of large shareholders seemed to support linear hedging. Table 3 also indicates that firms whose directors had more wealth invested in the firm's stock belonged to the group of linear hedgers. With respect to the CEO portfolio variable, firms using linear contracts showed the highest proportion of CEO shares and the lowest proportion of CEO stock option compensation. CEOs with high levels of options compensation preferred to hedge with put derivatives. This result is consistent with compensation incentive-based theories, which predict that shares promote risk-adverse behavior, while stock options encourage risk-taking.

Table 3. Univariate analysis

\begin{tabular}{|c|c|c|c|c|c|c|}
\hline \multirow[b]{2}{*}{ Variables } & \multirow{2}{*}{$\begin{array}{c}\text { I } \\
\text { Linear } \\
\text { contracts only }\end{array}$} & \multirow{2}{*}{$\begin{array}{l}\text { II } \\
\begin{array}{l}\text { Long puts and linear } \\
\text { contracts }\end{array}\end{array}$} & \multirow{2}{*}{$\begin{array}{c}\text { III } \\
\begin{array}{c}\text { Collars and linear } \\
\text { contracts }\end{array} \\
\end{array}$} & \multicolumn{3}{|c|}{$t$-statistics and $z$-scores } \\
\hline & & & & II vs. I & III vs. I & III vs. II \\
\hline \multirow[t]{2}{*}{ Cash costs } & 355.393 & 295.929 & 321.993 & 1.064 & 0.712 & -0.748 \\
\hline & (279) & (275) & (320.406) & -0.518 & -0.243 & -1.321 \\
\hline \multirow[t]{2}{*}{ Leverage } & 0.232 & 0.208 & 0.276 & 0.302 & -0.600 & -0.796 \\
\hline & $(0.224)$ & $(0.127)$ & $(0.194)$ & -0.442 & -0.486 & -1.203 \\
\hline \multirow[t]{2}{*}{ Expenditures ratio } & 0.042 & 0.169 & 0.073 & -1.432 & -0.824 & 0.996 \\
\hline & $(0.018)$ & $(0.011)$ & $(0.017)$ & -0.580 & -0.243 & -0.200 \\
\hline \multirow[t]{2}{*}{ Size } & 25.219 & 25.996 & 24.657 & -0.293 & 0.223 & 0.467 \\
\hline & $(22.764)$ & $(28.708)$ & $(21.685)$ & -0.403 & -0.182 & -0.520 \\
\hline \multirow[t]{2}{*}{ Quick ratio } & 1.746 & 3.796 & 2.378 & $-1.413^{*}$ & -0.864 & 0.906 \\
\hline & $(0.946)$ & $(1.371)$ & (1.614) & -0.710 & -1.580 & -0.120 \\
\hline \multirow[t]{2}{*}{ Unrelated directors shares } & 14.008 & 14.449 & 14.387 & -0.542 & -0.539 & 0.083 \\
\hline & (13.929) & $(14.788)$ & $(14.305)$ & -1.017 & -0.547 & -0.480 \\
\hline \multirow[t]{2}{*}{ Institutional investor } & 0.048 & 0.053 & 0.049 & -0.241 & -0.049 & 0.170 \\
\hline & (0) & (0) & (0) & -0.271 & -0.101 & -0.201 \\
\hline \multirow[t]{2}{*}{ Block holder } & 0.081 & 0.061 & 0.059 & 0.450 & -0.529 & 0.043 \\
\hline & (0) & $(0)$ & (0) & -0.146 & -0.454 & -0.335 \\
\hline \multirow[t]{2}{*}{ CEO shares } & 12.608 & 12.405 & 11.990 & 0.305 & 1.120 & 0.604 \\
\hline & $(12.548)$ & (11.927) & $(12.657)$ & -1.017 & -0.669 & -0.320 \\
\hline \multirow[t]{2}{*}{ CEO stock options } & 0.330 & 0.496 & 0.495 & $-1.662 *$ & $-1.80 * *$ & 0.008 \\
\hline & $(0.2840)$ & $(0.398)$ & $(0.470)$ & -1.248 & -1.763 & -0.361 \\
\hline Firm-strategy observations & 19 & 13 & 18 & & & \\
\hline
\end{tabular}

Note. The table lists descriptive statistics of the sample firms by hedging strategy. The top figures in each row represent averages, and the bottom figures refer to medians. We calculate time-series averages for each firm-strategy in order to ensure independent observations in each category, i.e. if a firm used the same strategy for more than one year, then firm-years with the same strategy are condensed into one observation by calculating means of the explanatory variables. The last three columns present statistics and tests comparing hedging strategies each other; $t$-tests, assuming unequal variances, test for differences in means (top figure); z-scores, based on the Wilcoxon Rank-sum, test for differences in distributions (bottom figure). Variables definitions can be found in Table 1. Significance at the 5\% and $10 \%$ levels is denoted by $* *$ and $*$, respectively.

\subsection{Multivariate Analysis}

We examined the relation between firms' hedging strategies and corporate governance variables by estimating several models. Our dependent variables were dummy variables and we compared the following hedging strategies: linear strategies (selling linear contracts such as forwards, spot-deferred contracts, and gold loans), insurance strategies (buying put options only), and collar strategies (buying collars).

Initially, we tried a multinomial logit estimation of the decision to select one of the three hedging strategies. Since our focus was why firms use options, linear contracts strategy was chosen as the base case. The multinomial logit model was constrained by the independence of irrelevant alternatives (IIA) assumption. The rejection of the IIA assumption using this data set indicated that the multinomial logit model did not seem 
appropriate (Note 6). In this case, a probit or logit model was recommended. Finally, to analyze the relation between firms' hedging strategies and governance variables, we chose a probit model. Unfortunately, the challenge of this model was the sample size (Note 7). The data included observations on an unbalanced panel of 30 firms per year for 17 years. To account for the panel nature of the data, we estimated both random effects and simple probit models. In addition, the reported standard errors in the probit model were calculated to control for heteroscedasticity. Results are summarized in Table 4.

Table 4 contains three probit regressions: (1) insurance versus linear strategy, (2) collar versus linear strategy, and (3) collar versus insurance strategy. The goal of this study was to analyze which governance attributes explain why a firm prefers one strategy over another. To the best of our knowledge, this study was the first to analyze the impact of organizational structure on the choice of hedging strategy.

Table 4. Determinants of derivative instrument choice using probit model

\begin{tabular}{|c|c|c|c|}
\hline Variables & Insurance vs. linear strategy & Collar vs. linear strategy & Collar vs. insurance strategy \\
\hline \multirow[t]{2}{*}{ Intercept } & $3.6621 *$ & -0.6130 & $-4.2346^{* * *}$ \\
\hline & $(0.077)$ & $(0.747)$ & $(0.014)$ \\
\hline \multirow[t]{2}{*}{ Cash costs } & -0.0021 & -0.0013 & 0.0031 \\
\hline & $(0.197)$ & $(0.277)$ & $(0.124)$ \\
\hline \multirow[t]{2}{*}{ Leverage } & -0.5113 & $1.2255 * *$ & $2.0905 * * *$ \\
\hline & $(0.615)$ & $(0.041)$ & $(0.007)$ \\
\hline \multirow[t]{2}{*}{ Expenditures ratio } & $2.3345^{*}$ & 2.4246 & -0.8652 \\
\hline & $(0.075)$ & $(0.125)$ & $(0.121)$ \\
\hline \multirow[t]{2}{*}{ Size } & 0.0457 & $0.0365^{*}$ & 0.0328 \\
\hline & $(0.158)$ & $(0.068)$ & $(0.161)$ \\
\hline \multirow[t]{2}{*}{ Quick ratio } & $0.2108 * * *$ & 0.0464 & $-0.1230 * *$ \\
\hline & $(0.001)$ & $(0.387)$ & $(0.012)$ \\
\hline \multirow[t]{2}{*}{ Unrelated directors shares } & 0.0956 & -0.0360 & $-0.0964 * *$ \\
\hline & $(0.376)$ & $(0.614)$ & $(0.014)$ \\
\hline \multirow[t]{2}{*}{ Institutional investor } & $-9.3333^{* *}$ & 1.6666 & $11.8580 * * *$ \\
\hline & $(0.037)$ & $(0.424)$ & $(0.000)$ \\
\hline \multirow[t]{2}{*}{ Block holder } & -3.1813 & -1.5058 & 0.8928 \\
\hline & $(0.179)$ & $(0.242)$ & $(0.551)$ \\
\hline \multirow[t]{2}{*}{ CEO shares } & $-0.5426 * * *$ & -0.0075 & $0.2864 * *$ \\
\hline & $(0.001)$ & $(0.943)$ & $(0.014)$ \\
\hline \multirow[t]{2}{*}{ CEO stock option compensation } & $1.4412 * *$ & $0.7256^{*}$ & 0.6489 \\
\hline & $(0.040)$ & $(0.084)$ & $(0.273)$ \\
\hline Number of observation & 71 & 94 & 73 \\
\hline$p$-value & 0.0106 & 0.0836 & 0.0017 \\
\hline Pseudo $R^{2}$ & $38.49 \%$ & $12.79 \%$ & $27.79 \%$ \\
\hline
\end{tabular}

Note. This table presents results from a probit model testing the decision to select one of the three hedging strategies listed in table 3 . The dependent variables are equal to zero for linear strategy only and equal to one for insurance strategy, and collar strategy. Dependent variable for the last column is equal to one for collar strategy and zero for insurance strategy. The independent variables are defined in Table 1. Figures in parentheses denote heteroskedasticity-robust p-value statistics. Significance at the $1 \%, 5 \%$ and $10 \%$ levels is denoted by $* * *, * *$, and ${ }^{*}$, respectively.

\subsubsection{Insurance versus Linear Hedging Strategies}

Column 1 of Table 4 evaluates the differences between firms that used insurance strategies (long puts) and firms that used linear strategies only. The use of insurance strategies was a dummy variable that equalled one if a firm used put options and zero if a firm used linear hedging instruments.

Results indicated that the use of put options was negatively correlated with the importance of the presence of institutional investors on the board of directors. Institutional investors therefore appear to encourage firms to select hedging strategies based on linear contracts rather than long put contracts. These results were consistent with the hypothesis that institutional investors are more conservative and generally less diversified, since they have committed a large amount of capital to the firm (Ferreira \& Matos, 2008). The negative coefficient of blockholders in the regression may indicate that linear strategy hedgers have more institutional investors as shareholders. Institutional investors likely prefer the protection offered by a linear hedging program. 
The panel data also showed that the coefficient on the CEO portfolio's shares was negative and significant with the use of an insurance strategy, which indicated a motivation for managers to prefer linear hedging when the number of shares the managers hold increases. However, when the proportion of options in the CEO compensation package rose, firms selected put options strategies. This result is consistent with Smith and Stulz (1985)'s hypothesis based on managerial incentives: managers are usually less diversified than regular shareholders because their financial and human capital is tied to their firms' well-being. The greater the managers' human capital investment or equity investment in the firm, the greater their incentive to lower risk through hedging. In this case, CEOs may have incentive to choose linear hedging strategies. However, when CEO options ownership increases, CEO wealth becomes more sensitive to upside changes in stock prices, making linear hedging less desirable. Options holdings make CEOs less risk-averse and create a preference for a long put strategy to maintain some upside potential.

Results also indicated that firms with a higher liquidity ratio (quick ratio) relied more on insurance strategies than linear hedging strategies to manage their gold price exposures. These firms likely faced low financial constraints, so this result was consistent with Detemple and Adler (1988)'s hypothesis that companies with low financial constraints are more likely to adopt options strategies. Column 1 of Table 4 also indicated a positive relation between put options and firms' capital expenditures. Insurance strategies were likely used more than linear strategies in large investment programs. This result confirmed Froot et al. (1993)'s hypothesis that firms hedge their capital expenditures and that the optimal hedging strategy in the case of cash outflows that are superior to cash inflows is an options strategy.

\subsubsection{Collar versus Linear Hedging Strategies}

Column 2 of Table 4 shows a probit regression where the dummy variable equals one if a firm used put and call options (collar) and zero if it used linear hedging instruments. Results indicated that a significant difference exists between firms using collar strategies and firms using linear strategies only.

Collar hedgers corroborated the hypothesis for financial constraints and CEO incentives, although statistically significant variables were different from those identified for insurance hedgers. Compared to firms using linear contracts, firms using collar instruments were larger and had higher debt levels. Also, when CEO stock option portfolios increased, so did the probability that a firm would prefer collar derivatives. Note that the impact of the variable measuring CEO stock options was larger in the group of firms adopting insurance hedging than in the group of firms adopting collar hedging (this variable is statistically significant at 5\% and 10\% respectively).

\subsubsection{Collar versus Insurance Strategies}

The last column in Table 4 evaluates the differences between firms that used collar strategies and firms that used insurance strategies. The dependent variable was a dummy variable that equalled one if a firm used collar strategies and zero if a firm used insurance strategies. Collar strategies were similar to insurance strategies, except that the purchase of the puts was partially financed by the sale of calls. A firm that did not have the financial resources for a pure insurance strategy could therefore choose a collar hedging strategy to maintain some upside potential. A collar hedging strategy maintains less upside potential than a pure put strategy, but a collar hedging strategy is less expensive.

Although firms choosing collar strategies had high leverage and therefore appeared less financially constrained, they were more likely to suffer from liquidity difficulties measured by quick ratio. This result consolidated the idea that firms preferring to maintain some upside potential but suffering from a lack of liquidities partially financed the purchase of puts through the sale of calls.

Table 4 shows that when compared to insurance hedgers, collar hedgers presented an organizational structure in which both of the number of institutional investors on the board of directors and the CEO ownership were relatively high. These findings indicate that when firms have a strong institutional investor presence and a risk-averse CEO profile, their preference is toward collar derivatives rather than put derivatives.

The variable measuring the percentage of outside directors on the firm's board indicated mixed empirical findings. Fama and Jensen (1983) argued that outside directors have a greater incentive to make decisions that benefit shareholders than inside directors. Outside directors are viewed as superior monitors because their careers are less likely to be tied to that of the CEO and consequently, they are free to make objective decisions. Concern for their reputation in the labor market also provides outside directors with an incentive to act in the best interest of majority shareholders. The sign of this variable was assumed to follow the sign of the variables related to institutional investors or blockholders. Table 4 shows that the involvement of this variable in selecting a hedging strategy is unclear. 


\subsection{Robustness: Do Market Conditions Affect the Choice of Hedging Instruments?}

In this section, we will analyze how changing market conditions can impact firms' hedging instruments and how expectations about future spot prices affected the choice of spot-deferred contracts, forwards, or options to hedge an exposure. For example, in certain situations where the gold price was particularly low, managers could avoid blocking the current gold price with a forward contract and instead hedge by buying put options to maintain the upside potential. Managers could also decide not to buy options if gold price volatility was high because options seemed expensive (Adam, 2009). Practitioners often argue that forward gold sales are more profitable when the gold basis (difference between the forward and the spot price of gold) is significant.

The period considered in this paper is from 1996 to 2012, a period that saw major disruptions in financial markets, particularly those related to the financial crisis of 2007-2008. To characterize the major disturbance experienced by the gold market, we introduced gold price volatility as an independent variable in the probit regression. The time-series graphs of gold price volatility between 1996 and 2012 are shown in Figure 1.

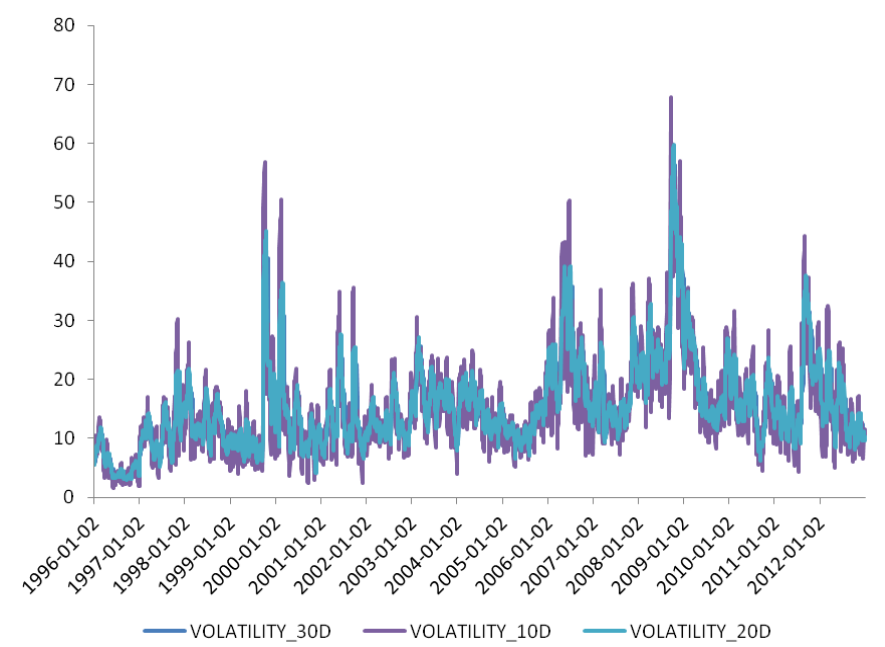

Figure 1. The gold price volatility over 1996-2012 priod of study

Note. It is measured by the standard deviation of daily gold price using a 30-day window, a 10-day window and a 20-day window. Information on gold price volatility is obtained from Compustat.

The gold price volatility retained for the regression model to analyze the determinants of hedging strategies was 30-day volatility. The average of this standard deviation was calculated to get an annual volatility. Table 5 presents probit regression results for the decision to select one of the three hedging strategies. Even when gold price volatility was considered, the results reported in Table 5 were similar to the results in Table 4 .

Table 5. Determinants of derivative instruments' choice considering gold price volatility

\begin{tabular}{lccc}
\hline Variables & Insurance versus linear strategy & Collar versus linear strategy & Collar versus insurance strategy \\
\hline Intercept & 3.4299 & -0.6931 & $\mathbf{- 4 . 2 3 4 5 * *}$ \\
& $(0.125)$ & $(0.724)$ & $(0.015)$ \\
Cash costs & $\mathbf{- 0 . 0 0 3 1 ^ { * }}$ & $\mathbf{- 0 . 0 0 2 3 *}$ & 0.0033 \\
& $(0.090)$ & $(0.092)$ & $(0.106)$ \\
Leverage & -0.3240 & $\mathbf{1 . 4 5 9 4 * *}$ & $\mathbf{1 . 9 4 6 1}^{* *}$ \\
& $(0.752)$ & $(0.022)$ & $(0.014)$ \\
Expenditures ratio & $\mathbf{2 . 4 2 4 4 *}$ & $\mathbf{3 . 6 3 1 8 * *}$ & $\mathbf{- 1 . 0 6 8 8} *$ \\
Size & $(0.051)$ & $(0.037)$ & $(0.064)$ \\
& 0.0466 & $\mathbf{0 . 0 3 9 8} * *$ & 0.0308 \\
Quick ratio & $(0.154)$ & $(0.050)$ & $(0.197)$ \\
& $\mathbf{0 . 2 3 5 6 * * *}$ & 0.0757 & $\mathbf{- 0 . 1 2 4 8 * *}$ \\
Unrelated directors shares & $(0.004)$ & $(0.200)$ & $(0.010)$ \\
& 0.0777 & -0.0556 & -0.0622 \\
\end{tabular}




\begin{tabular}{|c|c|c|c|}
\hline Institutional investor & $\begin{array}{c}\mathbf{- 8 . 8 6 0 8} * * \\
(0.039)\end{array}$ & $\begin{array}{l}1.5467 \\
(0.459)\end{array}$ & $\begin{array}{c}\text { 11.5866**** }^{* *} \\
(0.000)\end{array}$ \\
\hline Block holder & $\begin{array}{c}\mathbf{- 4 . 0 8 9 3 *} \\
(0.085)\end{array}$ & $\begin{array}{c}-1.4614 \\
(0.279)\end{array}$ & $\begin{array}{l}0.6480 \\
(0.678)\end{array}$ \\
\hline CEO shares & $\begin{array}{c}-\mathbf{0 . 5 5 8 8} * * * \\
(0.001)\end{array}$ & $\begin{array}{l}-0.0297 \\
(0.781)\end{array}$ & $\begin{array}{c}\mathbf{0 . 2 8 9 1} * * \\
(0.012)\end{array}$ \\
\hline CEO stock option compensation & $\begin{array}{c}\mathbf{1 . 6 1 9 7} * * \\
(0.020)\end{array}$ & $\begin{array}{c}\mathbf{0 . 8 0 3 8} * \\
(0.060)\end{array}$ & $\begin{array}{l}0.4935 \\
(0.402)\end{array}$ \\
\hline Gold price volatility & $\begin{array}{l}0.0615 \\
(0.170)\end{array}$ & $\begin{array}{l}0.0511 \\
(0.125)\end{array}$ & $\begin{array}{l}-0.0285 \\
(0.474)\end{array}$ \\
\hline Number of observation & 71 & 94 & 73 \\
\hline$p$-value & 0.0024 & 0.0653 & 0.0011 \\
\hline Pseudo $R^{2}$ & $40.20 \%$ & $14.57 \%$ & $28.20 \%$ \\
\hline
\end{tabular}

Note. This table presents results from a probit model. The dependent variables are equal to zero for linear strategy and equal to one for insurance strategy and collar strategy. Dependent variable for the last column is equal to one for collar strategy and zero for insurance strategy. The independent variables are defined in Table 1. Figures in parentheses denote heteroskedasticity-robust p-value statistics. Significance at the $1 \%, 5 \%$ and $10 \%$ levels is denoted by $* * *, * *$, and *, respectively.

\section{Conclusion}

Several studies have tried to predict why and how firms select derivative instruments to hedge their financial risk. The majority of these studies were theoretical models and attempted to rationalize the hedging strategy and linear versus non-linear derivative choice using various financial attributes of the firms. The use of corporate governance characteristics to explain hedging strategy choice remains largely uninvestigated.

Our paper contributes to an emerging body of research that attempts to explain firms' choice of hedging strategy. This study investigates which governance attributes firms should determine hedging instruments' choice. We conducted a survey of 30 North American gold mining companies over a 17-year horizon between 1996 and 2012. The gold mining industry is an excellent sector for studying derivative instruments because gold mining firms provide detailed information on their hedging portfolios and the nature of the instruments used. In addition, although gold mining firms all face the same risk exposure - the fluctuation in the future price of gold - they use various hedging strategies. Differences in hedging strategies are therefore more likely to be the result of differences in firm-specific characteristics than differences in exposures.

This study produced interesting results. The use of options was negatively correlated with the presence of institutional investors on the board of directors. These investors appeared to encourage firms to select hedging strategies based on linear contracts. The same attitude was observed for blockholders. Firms selecting linear strategies likely had more institutional investors as large shareholders. Thus, firms whose boards had a strong presence of institutional investors as directors were more likely to defend shareholders' interest in decisions on how to hedge firm exposure.

This study also showed that firms whose managers had risk incentives induced by stock option compensation were more likely to use options than other firms. Conversely, the greater the managers' equity investment in the firm, the greater their incentive to choose linear hedging strategies. This result was consistent with the hypothesis based on managerial incentives: when CEO options ownership increased, CEO wealth became more sensitive to upside changes in stock prices, making linear hedging less desirable. However, options holdings made CEOs less risk-adverse and created a preference for a long put strategy to support more risk and maintain some upside potential.

\section{References}

Adam, T. (2002). Risk management and the credit risk premium. Journal of Banking and Finance, 26(2-3), 243-269. https://doi.org/10.1016/S0378-4266(01)00221-7

Adam, T. (2009). Capital expenditures, financial constraints, and the use of options. Journal of Financial Economics, 92(2), 238-251. https://doi.org/10.1016/j.jfineco.2008.04.007

Adler, M., \& Detemple, J. B. (1988). Hedging with futures and options. Studies in Banking and Finance, 5(4), 181-197.

Bettis, J. C., Bizjak, J. M., \& Kalpathy, S. L. (2015). Why do insiders hedge their ownership? An empirical examination. Financial Management, 44(3), 655-683. https://doi.org/10.1111/fima.12083 
Borokhovich, K. A., Brunarski, K. R., Crutchley, C. E., \& Simkins, B. J. (2004). Board composition and corporate use on interest rate derivatives. Journal of Financial Research, 27(2), 199-216. https://doi.org/10.1111/j.1475-6803.2004.t01-1-00079.x

Detemple, J., \& Adler, M. (1988). Hedging with futures and options, Studies in Banking and Finance, 5(2), 181-197.

Dionne, G., \& Triki, T. (2005). Risk management and corporate governance: The importance of independence and financial knowledge for the board and the audit committee. Working paper, CIRPÉE. https://doi.org/10.2139/ssrn.686470

Fama, F. F., \& Jensen, M. C. (1983). Separation of ownership and control. Journal of Law and Economics, 26(2), 301-325. https://doi.org/10.1086/467037

Ferreira, M., \& Matos, P. (2008). The colors of investors' money: The role of institutional investors around the world. Journal of Financial Economics, 88(3), 499-533. https://doi.org/10.1016/j.jfineco.2007.07.003

Froot, K. A., Scharftein, D. S., \& Stein, J. C. (1993). Risk management: Coordinating corporate investment and financing policies. Journal of Finance, 48(5), 1629-1658. https://doi.org/10.2307/2329062

Géczy, C., Minton, B. A., \& Schrand, C. (1997). Why firms use currency derivatives. Journal of Finance, 52(4), 132-154. https://doi.org/10.2307/2329438

Haushalter, G. D. (2000). Financing policy, basis risk and corporate hedging: Evidence from Oil and Gas producers. Journal of Finance, 55(1), 107-152. https://doi.org/10.1111/0022-1082.00202

Hausman, J., \& McFadden, D. (1984). Specification tests for the multinational logit model. Econometrica, 52(5), 1219-1240. https://doi.org/10.2307/1910997

Knopf, J. D, Nam, J., \& Thornton, JR J. H. (2002). The volatility and price sensitivities of managerial stock option portfolios and corporate hedging, Journal of Finance, 57(2), 801-825. https://doi.org/10.1111/1540-6261.00442

Lel, U. (2012). Currency hedging and corporate governance: A cross-country analysis. Journal of Corporate Finance, 18(2), 221-237. https://doi.org/10.1016/j.jcorpfin.2011.12.002

Marsden, A., \& Prevost, A. K. (2005). Derivative use, corporate governance, and legislative change: An empirical analysis of New Zealand listed companies. Journal of Business Finance \& Accounting, 32(1-2), 255-295. https://doi.org/10.1111/j.0306-686X.2005.00594.x

Rajgopal, S., \& Shevlin, T. (2002). Empirical evidence on the relation between stock option compensation and risk taking. Journal of Accounting and Economics, 33(2), 145-171. https://doi.org/10.1016/S0165-4101(02)00042-3

Rogers, D. A. (2002). Does executive portfolio structure affect risk management? CEO risk-taking incentives and corporate derivative usage. Journal of Banking \& Finance, 26(2-3), 271-295. https://doi.org/10.1016/S0378-4266(01)00222-9

Smith, C. W., \& Stulz, R. M. (1985). The determinants of firms' hedging policies. Journal of Financial and Quantitative Analysis, 20(4), 391-405. https://doi.org/10.2307/2330757

Stulz, R. M. (1996). Rethinking Risk management. Journal of Applied Corporate Finance, 9(3), 8-24. https://doi.org/10.1111/j.1745-6622.1999.tb00027.x

Tufano, P. (1996). Who manages risk? An empirical examination of risk management practices in the gold mining industry. Journal of Finance, 51(4), 1097-1137. https://doi.org/10.1111/j.1540-6261.1996.tb04064.x

Whidbeea, D. A., \& Woharb, M. (1999). Derivative activities and managerial incentives in the banking industry. Journal of Corporate Finance, 5(3), 251-276. https://doi.org/10.1016/S0929-1199(99)00005-X

\section{Notes}

Note 1. A gold loan or loan against gold is technically equivalent to a cash loan and a forwards portfolio. A spot-deferred contract, also called an undated forward, is similar to a forward contract except that it gives the seller the option to roll the contract forward rather than make delivery on a specific date. There is no cash flow when a spot-deferred contract is rolled over.

Note 2. The majority of gold mining firms tend to use forward sales instead of futures contracts to avoid the cash 
margin calls that futures transactions could entail.

Note 3. Knopf et al. (2002) used delta and vega measures in their analysis. Delta measures the sensitivity of a manager's stock and stock option portfolio to stock price changes; as the stock price increases (decreases), option value increases (decreases), so managers may be motivated to hedge more (hedge less). Vega measures the sensitivity of a manager's stock option portfolio to changes in stock return volatility. Because of the convex payoff structure of options, increased stock volatility increases the value of stock options, thus giving managers an incentive to hedge less.

Note 4. The definition of hedging strategies is similar to Adam's definition (2009).

Note 5. Selling options have not been analyzed in this study because of the lack of observations.

Note 6. The Hausman test determines whether to reject the IIA assumption (Hausman and McFadden, 1984).

Note 7. Sample size in this kind of study is a challenge because data are generally collected by hand.

\section{Copyrights}

Copyright for this article is retained by the author(s), with first publication rights granted to the journal.

This is an open-access article distributed under the terms and conditions of the Creative Commons Attribution license (http://creativecommons.org/licenses/by/4.0/). 